\title{
The Pursuit of External Knowledge in Eco-Innovation. Analysis of the Agri-Food Sector in Spain
}

$\begin{array}{r}\text { Laura M. Avellaneda-Rivera } \\ \text { laura.avellaneda@uclm.es }\end{array}$
Universidad de Castilla-La Mancha, Spain
Ángela González-Moreno
angela.gonzalez@uclm.es
Universidad de Castilla-La Mancha, Spain
Francisco J. Sáez-Martínez
francisco.saez@uclm.es
Universidad de Castilla-La Mancha, Spain

\begin{abstract}
The research about the search for opportunities through open cooperation strategies points to an exchange of knowledge among a certain number of sources, aimed at sustaining competitive advantage. From this new vision emerges the paradigm of open innovation, which has prompted a change in the organization of resources, information filtering, and rapid absorptive capacity. Awareness of climate problems and external societal pressures can motivate companies to create new technologies and new forms of cooperation to avoid environmental problems. Based on a survey of Spanish agri-food firms, we find that the depth of external sources of innovation increases environmental improvement in a U-shaped relationship.
\end{abstract}

Keywords: Open innovation, depth, breadth, diversity, environmental innovation. 


\section{Introduction}

In the current globalized market, innovation is more important than ever to the growth and success of firms, no matter the sector. Traditionally, firms have generated new knowledge by exploiting their internal $R+D$ resources (Mowery, 1992), and the innovation process has depended on their own resources. A firm's decision between doing or buying can prompt managers to explore new and varied sources of knowledge. Politics for promoting innovation must be efficient, reflecting the ways in which changes in the running of firms now take place, as well as the intense flow of information of today (Hewitt-Dundas \& Roper, 2017; Bogers, Chesbrough \& Moedas, 2018). Transforming ideas into results for firms necessitates a range of complementary activities, such as organizational changes, training at all hierarchal levels, marketing tools, and job design (OCDE, 2010).

Amidst this shift in the outlook of the innovation process, open innovation emerged as a field of research, and has gone on to grow exponentially in recent years (West \& Bogers, 2017). This paradigm proposes, above all, the reorganization of resources, information filtering, horizontal collaboration with other partners in common processes, rapid knowledge absorption, and maximum learning power (Lichtenthaler, 2009; Kostopoulos et al., 2010; Chesbrough 2003; Cohen \& Levithal, 1990). Despite increasing interest in open innovation, many authors criticize the absence of research into its application by firms (Lee et al., 2010; Steen \& Vanhaverbeke, 2016; Del Río, Peñasco \& RomeroJordán, 2016; Bossle et al., 2016). However, we note that the prospects of achieving innovation through external cooperation are very good (Cohen \& Levinthal, 1990; Van de Vrande et al., 2009), in that 95\% of Spanish firms are SMEs with common characteristics in terms of investment in innovation.

In the innovation process, knowledge management is a requirement for undertaking $R+D$ activities that involve the creation of new technology. This usage does not always owe entirely to commercial ends, and can also entail reduction of production costs or waste, which in turn favors the environment. From there, the notion of eco-innovation emerges. Awareness of climate problems and society's external pressures can encourage companies to create new technologies and seek out external sources aimed at preventing environmental degradation or developing energy-saving technologies to mitigate climate change (Rennings, 2000).

As such, our first objective is to analyze whether external cooperation is effective in promoting environmental improvements within firms. We have also noted a lack of research on networks in the agri-food sector, in which technological upgrades are not always leveraged (Cuerva, Triguero \& Córcoles, 2014), products are generally homogeneous, and the customer plays an important role in possible shifts towards healthy eating (Sarkar \& Costa, 2008; Zhuan et al., 2016; Hölzl, 2009).

The agri-food sector in Spain contributes to economic growth with a high share of industrial activity - greater in relative terms than the European average and outstripping most EU member states (Gandoy \& González, 2004) - and a high volume of manufacturing firms active in the sector. Our second objective is to establish whether open innovation as a strategy exhibits any network patterns that could drive environmental improvements in the products and services that the sector develops. 
Avellaneda-Rivera, L.M., González-Moreno, A. \& Sáez-Martínez, F.J. (2018). The Pursuit of External Knowledge in Eco-Innovation. Analysis of the Agri-Food Sector in Spain. Journal of Business, Universidad del Pacífico (Lima, Peru) Vol.10 (1): 70-92

\section{Conceptual framework}

In this section we explore certain key concepts on open innovation, characteristics of the cooperation network, and relevant aspects of eco-innovation.

\section{Open innovation}

More than ten years on from the publication of Chersbrough's (2003) book about the open innovation paradigm, a number of aspects have changed, serving both to enrich the definition and evolve the concept. The earliest research focused on the two-way exchange of ideas through open channels. But some authors (Laursen \& Salter, 2006) argue that firms may need this knowledge not only during the invention or brainstorming stages, but also at the marketing stage. Others propose that as well as economic relationships, cooperation can be motivated by questions of market survival (Bullinger et al., 2010), creation and recombination of technology (Katila \& Ahuja, 2002; Lee et al., 2010), or the pursuit of indirect benefits through organizational change within the firm (Dahlander \& Gann, 2010). Leiponen \& Helfat (2005) discovered, through Community Innovation Survey (CIS) data, the successful development of ideas based on "parallel approaches to innovation." Here, firms maintain an open strategy when it comes to harnessing and accessing ideas (breadth of sources), and develop a change of mentality regarding the new access routes to innovation (breadth of objectives). Scholars propose that companies must make a concerted effort to use knowledge inputs and outputs to hasten internal innovation, and to broaden markets for the external use of innovation, respectively (Brunswicker \& Vanhaverdeke, 2015). This way of acquiring, substituting, or complementing a firm's internal knowledge base through networks has been studied by many academics with an interest in the pursuit of market effectiveness (Laursen \& Salter, 2006); as such, the updated definition of open innovation, drawing on contributions made in the 14 years that followed its initial conceptualization, is the below:

"Open innovation is a distributed innovation process based on purposively managed knowledge flows across organizational boundaries, using pecuniary and non-pecuniary mechanisms in line with the organization's business model. (Chesbrough \& Bogers, 2014; p. 17).

\section{Open innovation network factors}

In this study, in respect of how this openness to innovation can be achieved and how establish external links are established, we have identified three key factors related to cooperation networks that can furnish us with information on how to bring external knowledge closer to companies.

The first factor is breadth in the pursuit of innovation, which generally refers to the number of links that the organization establishes with different knowledge sources. Firms can identify or search for external sources of innovation by collaborating with a variety of external actors or by seeking close relationships with more specific partners (Nieto \& Santamaría, 2007). In the literature, this term is defined as "the number of external sources or search channels that firms rely upon in their innovative activities" (Laursen \& Salter, 2006, p. 134), based on the notion of exploratory search; that is, those firms that search, in the broadest and most open way possible, for a number of external sources will generally acquire more knowledge, have more opportunities to generate exploratory organizational learning (March, 1991), and, in turn, improve their prospects of achieving positive results. The use of different sources of knowledge is determined by the accessibility of these sources, including the availability of technological opportunities, the degree of turbulence of the environment, and competition (Cohen \& Levinthal, 1990). The importance of appropriate knowledge management notwithstanding, the future 
actions of firms are linked to past experiences; that is, results obtained by way of external collaboration will lead to the creation of a broad and deep network of contacts related to problem solving or to the creation of new products.

A firm usually has to learn, by way of trial and error, how to obtain much knowledge from external sources. This requires considerable time and efforts to understand the norms, habits, and routines of the various channels of knowledge selected for cooperation. Organizations cannot determine whether a wide range of channels have been successfully leveraged, and can thus develop a "myopia" towards openness to innovation (Levinthal \& March, 1993) and resort back to putting faith in their own research (Laursen \& Salter, 2006). As companies develop mechanisms and routines for managing their knowledge alongside external sources, they learn to handle these processes efficiently; as such, after the learning experience, they obtain greater profitability from a broad network through a reduction in expenses and time, thus increasing the benefits.

Firms would appear to perceive the lack of suitable partners for cooperation as a major barrier to innovation. As a consequence, a suitable knowledge partner can become a crucial asset worth retaining for deep and sustained interactions. This determines the depth of the relationships. This network factor is defined as "the extent to which firms draw deeply from the different external sources or search channels" (Laursen \& Salter, 2006, p. 134). Firms with depth in their contact network are highly adept at adapting to change and, thus, at being innovators. Sustaining close contacts with external channels demands resources and attention. Thus, if a firm trusts in too many agents, it can end up with poor innovation results (Tejersen \& Patel, 2017). In one of the first studies on networks and the strength of links, Ahuja (2000) indicates that external cooperation will favor innovation results provided that the external knowledge of the agents does create information overlaps, creating a secure channel through which to foster knowledge transfer. But there are authors, such as Gulati, Nohria and Zaheer (2000), who suggest that this relationship will be affected by the involvement of moderating factors related to the sector or type of agent.

The literature on cooperation and the search for external sources has exhibited an interest in interaction with external agents, since this facilitates product marketing (Chersbrough, 2003). Open innovation proposes harnessing the innovation of agents beyond one's own geographical limits, which gives rise to more technological opportunities. Geographical diversity can be described as the nationality of origin of these collaborating agents. There is normally a limit on the number of new, useful ideas that can be created from a set of knowledge elements (Katila \& Ahuja, 2002), but when a large variety of knowledge sources is accessed, from different geographical locations, the possibilities of generating solutions for new product development increase (Katila \& Ahuja, 2002; Laursen \& Salter, 2006). The expansion of network diversity to include partners from multiple industries, organizations and countries will make it possible to obtain greater benefits in terms of resources and learning, as well as expanding the knowledge base. When a firm opens up to knowledge beyond its geographical and technological limits, this permits an acceleration in the development of incremental innovations, taking into account the crucial role of absorption capacity in innovative performance (Presutti et al., 2017).

\section{Eco-Innovation}

Awareness of climate problems and external societal pressures can encourage companies to create new technological patterns aimed at preventing environmental degradation or making energy-saving investments to mitigate climate change (Rennings, 2000). This leads to the notion of eco-innovation, defined as "the process of developing new products, processes or services which provide customer and business value but 
significantly decrease environmental impact." (Fussler \& James 1996, p. 364). The literature contains various studies that analyze the determining factors of environmental innovation (Del Rio et al., 2016; Horbach, Rammer \& Rennings, 2012), the earliest of which are dominated by neoclassical economic strands (Triguero, Moreno-Mondéjar \& Davia, 2013; Pereira \& Vence, 2012) in which the factors are classified into three main groups of motivations for environmental change: technology push, market pull, and regulatory push/pull (Rennings, 2000; Triguero et al., 2013). More recently, the evolutionary streams have developed an even more interactive perspective of the innovation processes, in which innovation is not considered as a mere response to the stimuli of supply and demand factors (Pereira \& Vence, 2012; González Moreno et al., 2013; Oltra, 2008); rather, it is the structural characteristics of the firm itself, known as internal and external factors, that respond to the stimuli and incentives of a large number of actors conditioned by the market situation and environmental policies. These factors are inter-related (Del Río, Peñasco \& Romero-Jordán, 2016) and affect a firm, immersed in a turbulent environment, in changing ways.

Various studies have classified the internal and external structures that affect ecoinnovation practices, which we summarize in figure 1.

Figure 1: Internal and external factors of eco-innovation
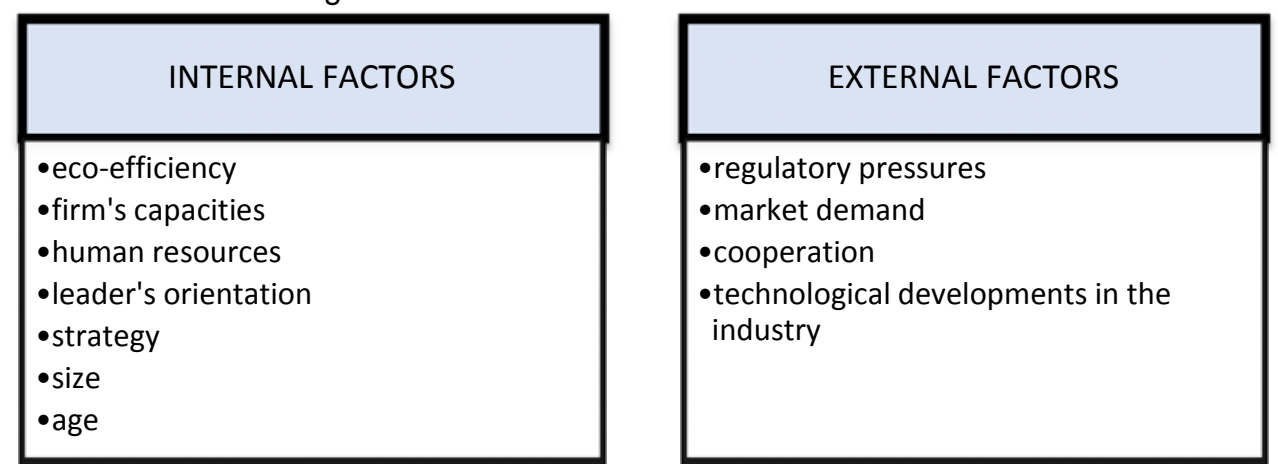

Source: Compiled by authors

One of the external factors that engenders environmental improvements is external cooperation (Carrillo-Hermosilla et al, 2010), given the dynamic and complex characteristics of eco-innovation. Firms need to learn how to quickly produce beyond their limits if they are not to lose market competitiveness. The importance of technical information obtained by external agents has been identified in the literature (Triguero et al., 2013) as a determinant of eco-innovation processes, albeit to a limited extent (SáezMartínez, Avellaneda-Rivera \& González-Moreno, 2016). Horbach (2008) observes positive results from collaboration, and states that eco-innovation processes involving collaboration with universities or research centers have been positive in terms of the use of materials and energy. Cainelli et al. (2012) argue that cooperation should be undertaken alongside actors with expertise in environmental solutions in order to yield positive results, since cooperation has a dual purpose: training and process modernization. Based on these studies, Del Rio et al. (2016) refer to the greater intensity and frequency of this cooperation when the intention is to explore new markets or create new products in the industrial sectors.

\section{Hypothesis}

The purpose or motivation of network breadth in achieving eco-innovation changes in the case of technological innovation. As evidence of the effectiveness of open innovation 
in eco-innovation, the work of Horback et al. (2013) confirms that eco-innovation requires more external sources of knowledge and information than general innovation (without an ecological focus). According to Montresor, Ghisetti \& Marzucchi (2013), this is because environmental innovations have an organizational component, which is manifested in environmental improvement models, and need to incorporate organizational innovations.

This can be explained by the fact that eco-innovation results often materialize as products that favor well-being and lead to environmental improvements, many of which are converted into public goods. The sectors of low technological intensity do not have conclusive results as far as eco-innovation is concerned. The underlying reason for this contradiction, as explained by Ghisetti et al. (2015), is that firms act out of motivation when conducting an external search. In this case, the authors suggest that the breadth of the network owes less to knowledge shortfalls than it does to a search for solutions to problems faced by firms. First, because of the lack of knowledge for adopting specific steering systems related to eco-innovation management. Second, because of complications in the regulation of changes associated with new environmental laws. The pressing needs arising from these general knowledge shortfalls are difficult to address internally by firms, or to cover by one or few external knowledge providers. The urge to achieve innovation means that the agent network will need to be broader in order to achieve this aim as swiftly as possible, since relying solely on knowledge generated internally makes for slow and costly processes.

Thus, based on these general arguments, our first hypothesis is as follows:

Hypothesis 1a: The breadth of external sources in cooperation relationships has a positive bearing on eco-innovation development.

According to Laursen \& Salter (2006), negative relationships can also be observed in the long run, in cases of excessive breadth in the network of contacts. Ideas reach a firm to be taken into account in the development of new products, and a certain level of attention and effort is required to manage the implementation of these ideas. As we have seen, the institutionalization and assimilation of external innovation, the combination with internal $\mathrm{R}+\mathrm{D}$, and the development of a product or service in line with the agents concerned, requires the attention of resources such as time, cost, and the human factor (Goerzen \& Beamish, 2005). This attention is the key element based on the theory of limited rationality proposed by Simon (1947). This theory holds that attention is the most important and valuable factor within an organization, and that optimal resource management in particular activities is a crucial factor in explaining why some firms are capable of adapting so efficiently to an environment. For Ocasio's (1997), organizational theory, decision-making is an action that requires "concentrate their energy, effort, and mindfulness on a limited number of issues and tasks"(Ocasio, 1997, p. 203). This theory suggests that poor distribution of company direction can result in too many (or too few) connections with external sources, and anticipates that there will be an optimal point of external sources of collaboration, and any excess or shortage thereof will precipitate inferior performances.

Openness to innovation through cooperation with external agents favors environmental results (De Marchi, 2012; Laperche \& Uzunidis, 2012; Mogensen et al., 2012), but we believe that in excess it can cause a downward trend in green innovation, as in the case of general innovation (Laursen \& Salter, 2006). This is because explicit and implicit costs in managing these sources (Ghisetti et al., 2015), process complexity, the assimilation of external technical knowledge required by the eco-innovator, and the scarcity of ecoefficiency-related competencies on the part of the firm, can all lead to greater pressure on the attention of the firm's resources. 
In accordance with these proposals, out next sub-hypothesis in relation to this effect is:

Hypothesis 1b: The relationship between the breadth of external sources and ecoinnovation development is inverted $U$-shaped.

In their study about network depth, Ghisetti et al., (2015) propose two main motives to confirm its positive influence on eco-innovation. Cognitive proximity is the first element that facilitates learning through the network, since it organizes a common cognitive space that allows for sharing, exploiting, and reconverting knowledge (Spila, Rocca \& Ibarra, 2009). A lack of cognitive proximity (distance) can reduce eco-innovation results, as firms tend to undergo a broadening of knowledge before achieving success (De Marchi, 2012). The distance grows when the alternative production of inputs of materials related to the environment is dissimilar to the primary business, and is difficult to understand or put into practice (Teece et al., 1997). In the acquisition of new technologies, firms find solutions through agents at a remove from their habitual network, at a certain (cognitive) distance from their initial base. A deeper interaction with distant external agents would give us better eco-innovation results. The second argument for the indispensability of network depth to eco-innovation is that firms appear to perceive a lack of suitable partners in cooperation as a significant barrier to innovation (Rennings \& Rammer, 2009; HewittDundas \& Roper, 2017). However, this process is reinforced when complemented by an interactive process, through which firms forge relationships with other firms and the different actors in their environment (Amara et al., 2008), since the probability of achieving eco-innovative processes also increases with the capabilities acquired by the firm through its deep interaction with the actors (Montresor et al., 2013). The creation of formal and informal links on aspects of knowledge with other agents provides additional inputs for the learning process, which create new opportunities for accessing information. Deep and sustained interaction with a suitable partner is decisive and, perhaps, a crucial asset in sustaining adequate knowledge, whose availability is limited; it is known as "learning by interacting" (Amara et al., 2008).

As such, following on from these general arguments, our second hypothesis is as follows:

Hypothesis 2a: Greater depth in cooperation relationships has a positive bearing on ecoinnovation development.

As contended by Simon (1947) with regard to the theory of limited rationality, the excessive search for external knowledge, and the limited capacity of an organization, can keep the learning acquired through external sources from yielding positive results in terms of environmental innovations. First, because of repeated use of the same trusted sources, which fail to obtain technology that is appropriate for addressing ecological problems; and second, because the increasing costs of obtaining this information are not offset by the results obtained. Ghisetti et al. (2015) suggest that a conflict exists between engagement in the intense pursuit of external knowledge and the capacity to implement environmental improvement measures, and that this may be even more marked than is the case for general innovation. The greater complexity and distance of the external knowledge required for the eco-innovator, on the one hand; and the relative scarcity of specific green competencies, on the other, can place more pressure on the attention of the firm's resources, thus hampering its performance.

On the basis of these conclusions, we can propose our next sub-hypothesis regarding eco-innovation:

Hypothesis 2b: The relationship between the depth of cooperation and eco-innovation development is inverted U-shaped. 
Geographical diversity (both national and international), has positive effects on ecoinnovation, although we have found little in the literature in this regard. The study by Peñasco, del Rio \& Romero-Jordán (2014) proposes that governments should foster cooperation with local and international agents as an effective means of triggering ecoinnovation. When it comes to promoting the internationalization of firms, there is a need to design instruments based on the particular characteristics of the sector rather than offering generic solutions. De Marchi (2012) notes that $R+D$ cooperation is important for a firm's environmental innovation results, because it reduces $R+D$ risks and costs (Yu \& Rhee, 2015), and that environmental results place more demands on the breadth than do those of general innovation.

Drawing on these premises, we formulate our next sub-hypothesis.

Hypothesis 3a: Greater geographical diversity in cooperation relationships has a positive bearing on eco-innovation development.

As shown by Goerzen \& Beamish (2005), the relationship between geographical diversity in open innovation and eco-innovation is non-linear. To explain their non-linear results, some researchers have suggested that in economies of scale, economic decline originates at the highest levels of the geographical sphere, because, in line with the proposals of Roth (1992), the dispersion of the interests of multiple actors can greatly increase the management of information-processing demands, since the organization becomes more complex, which hampers the attainment of eco-results. This involves uncertainty and expenditure, such as network coordination costs (Powell et al., 1996; Galang, 2014), knowledge absorption costs (Cohen \& Levinthal, 1990, Laursen \& Salter, 2006), and costs derived from opportunistic behavior (Faems et al., 2010). Moreover, if the geographical diversity is international, the cognitive distance will be greater, which increases spending on resources, and the time required for assimilation and usage, all the more.

With these findings established in relation to general innovation, we think that they can be extended to eco-innovation, which brings us to our next sub-hypothesis:

Hypothesis 3b: The relationship between the geographical diversity of the external sources and eco-innovation development is inverted U-shaped.

\section{Methodology}

\section{Agri-food sector}

Innovation plays an important role in agri-food, a key sector in an increasingly competitive environment in which the novelty of a product can be considered as a distinct advantage to industry (Costa \& Jongen, 2006). Specifically, food demand is rapidly evolving into a more personalized market (Boland, 2008). Increasingly, food consumers require health-oriented products tailored to their individual needs and preferences (Sarkar \& Costa, 2008). This new trend has prompted firms, on the one hand, to employ more sophisticated marketing techniques to gain a better understanding of the needs of differentiated consumers (Boland, 2008). And on the other, it has compelled firms in the sector to create products borne of radical innovation (and, thus, to assume even greater risks and uncertainty in their development) while adopting technologically innovative solutions.

As to supply chain organization, innovation remains a difficult and complex process for the food industry, mainly due to the number of actors participating in production. The actors involved in open cooperation can be small firms, in the form of intermediate 
customers or end users, whose heterogeneous and even contradictory requirements can be difficult for the firm to meet (Grunert, 2005). From these considerations, it can clearly be surmised that the innovation process must be handled not only within the individual firm, but beyond its limits, taking into account the value chain as a whole (Costa \& Jongen, 2006) in order to coordinate the multiple relationships with the different actors involved (Grunert, 2005; Vanhaverbeke \& Cloodt, 2006).

To access external knowledge, agri-food firms can establish more or less formal agreements with other actors in the same supply chain, or with external actors such as universities and research centers. Knudsen (2007) argues that individual food firms prefer to partner with agents in their own sector, which can lead to the overlap of knowledge and skills. This overlap is, in fact, believed to facilitate innovation management, and, therefore, is considered a factor that can increase the likelihood of success in the innovation process. However, firms pertaining to industries characterized by a higher level of innovation often develop their innovations outside that industry, in more technologically advanced sectors (Maula, Keil \& Salmenkaita, 2006).

Spain's agri-food sector is distributed across more than 22,447 firms (INE, 2014), equivalent to $12 \%$ of all the country's businesses. As to current spending on environmental issues, in 2014, the food sector accounted for the highest percentage of all industries, in terms of economic activities, with $27.8 \%$ (INE, 2014) - an increase of $8.5 \%$ from the previous year. The efforts made by this sector attest to the importance of improving the processes involved in reducing environmental impact.

\section{Methodology Application}

For the empirical analysis, we use a representative sample of Spanish firms taken from the Technological Innovation Panel (Panel de Innovación Tecnológica, PITEC). Anonymous data from this panel is available on the website of the Spanish Foundation for Science and Technology (Fundación Española para la Ciencia y la Tecnología). One of the main advantages of the PITEC is its leap from a cross-sectional database, with no time dimension, to a panel that allows much more accurate estimation of changes in firms over time, and facilitates the collection of more robust data that better reflect the firms' heterogeneous behavior.

We use the 2011 sample, which contains a total of 10,074 firms, of which we analyze the 592 that pertain to the agri-food sector. There is no clear consensus on the definition of environmental innovation, which often has two strands: measurement of the effect on the environment, and the innovator's intention to carry out these innovations. In table 1 we have included the objectives that comprise the eco-innovation construct.

Table 1 Objectives that comprise the eco-innovation construct

\begin{tabular}{ll}
\hline \multicolumn{1}{c}{$\begin{array}{c}\text { Degree of importance of the following } \\
\text { objectives: }\end{array}$} & Prior references: \\
\cline { 2 - 2 } OBJ 11 Lower environmental impact & De Marchi \& Grandinetti (2012); Del \\
OBJ 12 Improved employee health and safety & Rio et al. (2013); Weng, Chen \& Chen \\
OBJ 13 Compliance with environmental & (2015); Horbach (2008); Brunnermeier \\
regulations on health or safety. & $\begin{array}{l}\text { \& Cohen (2003); De Marchi (2012); } \\
\end{array}$ \\
& Hemmelskamp (1999) \\
\hline
\end{tabular}


The most difficult part is verifying the effect of a motivation that becomes a result, which in turn can give rise to a change (Carrillo-Hermosilla, Del Rio \& Konnola, 2010). For our model, we use a subjective measurement based on the motivation for the innovation. We construct a variable that unifies the objectives of eco-innovation that feature in the PITEC questionnaire as other objectives of technological innovation, as used in the studies by Reyes \& Sánchez-Medina (2016), and Segarra-Oña et al. (2011).

We use a reflexive scale to measure eco-innovation; that is, in our database we identify the responses assigned to the importance of the objectives on a scale of four items (the possible responses to which are high, medium, low, and not applicable) for objectives related to the improvement of environmental impacts, health, and safety. This is approach has already been taken in other studies (Horbach, 2008; De Marchi, 2012; Del Río et al., 2016). To aid in the interpretation of the results, and prevent distortions in understanding the effect of the independent variables, we recode the scores by assigning levels from 1 (not applicable) to 4 (high).

As an independent variable, the breadth of sources, in the PITEC questionnaire the firms were asked about the sources of knowledge with which they cooperate. Consequently, the variable breadth is a binary variable with values of 1 and 0 , where 1 means that the firm cooperates with these sources of knowledge, and 0 means that they do not use them; we construct the mean from the sum of each source of knowledge, such that the firm that uses at least one source of knowledge is assigned a value of 1 , and the firm that uses all sources of innovation is assigned a total value of 8 . As such, the greater the number of sources used by the firm, the greater its level of openness will be to developing strategies for pursuing external sources (Laursen \& Salter, 2006).

This measurement has been utilized and adapted by various empirical works in respect of its relationship with eco-innovation (Cainelli et al., 2015; Ketata et al., 2015; Ghisetti, Marzucchi \& Montresor, 2015); this illustrates the importance of studying breadth as far as innovation strategies are concerned.

The second independent variable is the depth of external relationships (the intensity of relationships with partners), whereby the measurement is represented by the interaction and intensity of each type of external partner in the innovation activities.

The depth of openness is based on the answers given by the survey respondents to the following question: "how important is cooperation with the following external partners in the innovation activities of your firm?" Responses may be based on a Likert scale with the following four points: high, medium, now, and not used. The minimum value will be 8 (total number of agents), while the maximum will be 32 (maximum score for the four agents).

The scores indicate the level of importance according to the type of innovation partner with which the firm cooperates, as indicated on the following table 2. These variables have been tested on innovation results such as those of Laursen \& Salter (2006); Chen et al. (2011); Arruda et al. (2013) and on eco-innovación (Ghisetti et al., 2015; Montresor et al.,2013). 
Table 2 List of agents that cooperate, according to PITEC (2011).

\begin{tabular}{l} 
Level of importance of these cooperation agents \\
\hline Firms in the group \\
Providers of equipment, material, components, or software \\
Customers \\
Sources of competitors or other firms in the same branch of market activity \\
Consultants, commercial laboratories, or private R+D institutes \\
Universities or other higher education centers \\
Public research bodies \\
Technology centers
\end{tabular}

To be able to analyze the effect of the geographical diversity of the external sources in open innovation, we gather our information by way of the question "what is the country of origin of the partner with which you cooperate?" We set four possible responses: your country, another European country, the United States, China or India, and other countries (not specified in the previous options). For the analysis of geographical diversity, we use four dichotomous variables by obtaining a value between 0 and 4 . The diversity of collaboration will increase along with the number of regions in which it is developed. On this basis, we interpret there to be no diversity in the collaboration of one region, and that another four regions represent greater diversity in this respect. This variable has already been tested by previous studies on innovation (Santamaría et al., 2016; Wu \& Wu, 2014; Srholec, 2015).

Figure 2 shows the model we test in this study - which focuses on the impact of the breadth of cooperation relationships, their depth, and the geographical diversity of the partners - has an influence on the development of environmental improvements in the agri-food sector. The model also includes control variables proposed in the literature Kesidou \& Derimel (2012); Ahuja \& Katila (2004); Laursen \& Salter (2006); DeMarchi (2012); Garriga et al. (2013); Cainelli et al. (2014); Chen et al. (2011) - such as age, size, and the belonging to groups such as those shown in the following equation.

$$
\begin{aligned}
& E_{i}=\alpha+\beta_{1} \text { LnTAMAÑ }_{i}+\beta_{2} \text { GROUP }_{i}+\aleph_{3} \text { EDAD }_{i}+\beta_{4} \text { BREADTH }_{i}+\aleph_{5} \text { DEPTH }_{i}+ \\
& \aleph_{6} \text { GEOGRAPHICAL DIVERSITY } \\
& i
\end{aligned}
$$

Figure 2: Model and hypothesis to be tested

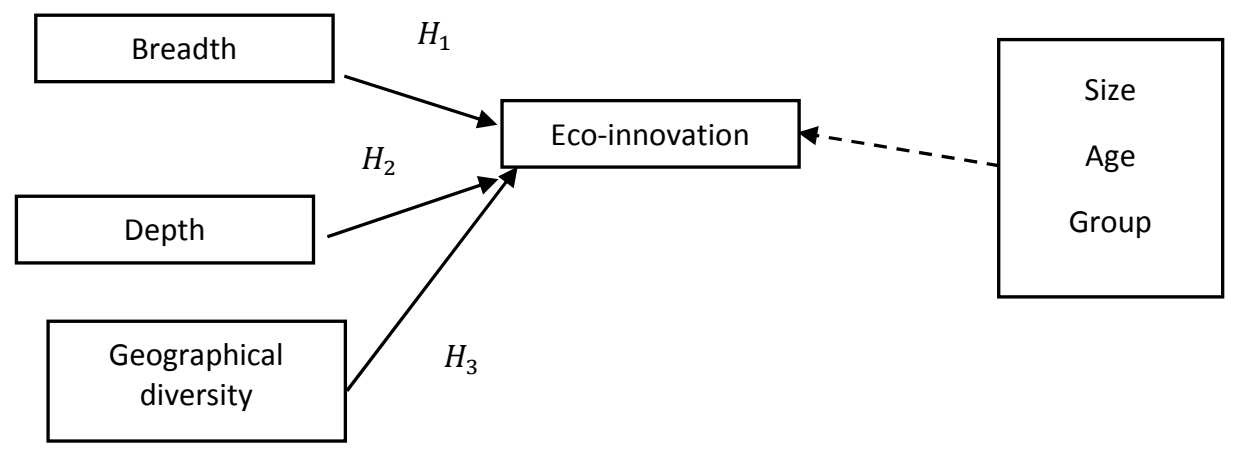




\section{Results}

Eco-innovation and green technology can be seen as a new challenge for many industrial firms (Horbach, 2014), creating interest in identifying possible risks before making an investment. From the point of view of the entrepreneur involved in the agri-food sector, the main driving force behind green actions ought to be a strategy that can protect its production capacity and value (Blasi et al., 2015).

The following graph provides a visual representation of the importance to the agri-food sector of the objectives involved in eco-innovation, expressing the percentages of importance of the objectives related to environmental matters. It can be seen that the greatest percentage is that corresponding to compliance with the regulations governing health and safety in environmental matters.

The regulations, as we have seen in the description of eco-innovation, constitute an important external factor for the motivation to eco-innovate. The food industry, through compliance with the legal stipulations imposed by governments, improves the quality of its products (Horbach, 2008). In this case, we note the relative weight in the agri-food sector, perhaps because non-compliance with such regulations might have more severe consequences here, since they directly concern health (Banerjee et al., 2003).

Graph 1: Statistical data on the importance of environmental objectives in the agri-food sector

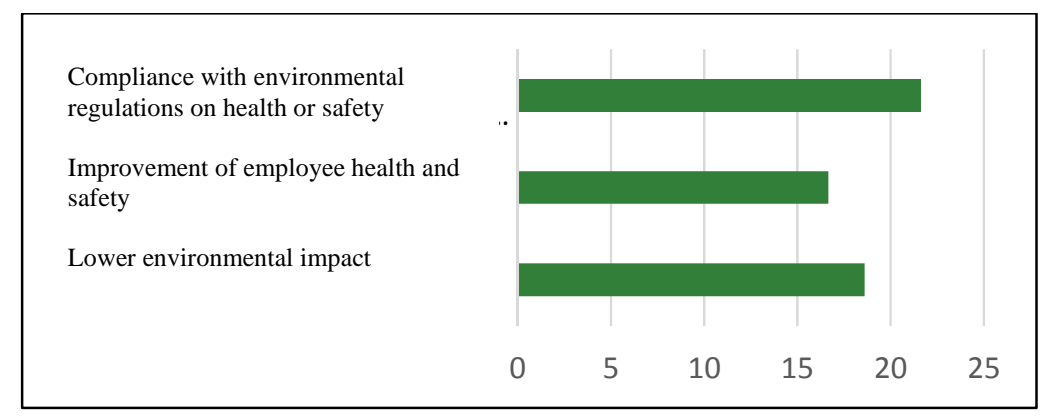

Source: Compiled by authors

Table 3. Factor analysis of the independent variable of eco-innovation in the agri-food sector.

\begin{tabular}{|l|c|}
\hline Lower environmental impact & 0.900 \\
\hline Improved employee health and safety & 0.931 \\
\hline Environmental, health or safety regulatory compliance & 0.904 \\
\hline
\end{tabular}

In the factor analysis (extraction) of the main components, the table 3 shows that the three variables corresponding to the items comprising the eco-innovation variable are greater than 0.707; these three variables are sufficient for explaining the dependent variable of eco-innovation, with a greater bearing on the objective of improving employee health and well-being. 
Having completed the statistical analysis of the variables, we will proceed to establish the sample reliability, as shown in table 4. According to the KMO index, a sampling adequacy of 0.75 (Angel, De la Fuente \& Vila, 2011) must be recorded for the sample to be considered as good (with a value of 0.743 ).

Table 4. Sample reliability

\begin{tabular}{ll}
\hline \multicolumn{2}{c}{ Eco-innovation } \\
\hline Explained variation & 83.153 \\
KMO & 0.743 \\
Barlett's & $1104.901^{* * * *}$ \\
Cronbach's alpha & 0.898 \\
\hline
\end{tabular}

$* * * \mathrm{p}>0.01$

Having established the reliability of the sample, we perform our first analysis through an ordinary least squares (OLS) regression to determine the relationship between ecoinnovation and the depth, breadth, and geographical diversity of the cooperation networks, and to determine whether there is an inverted $U$ effect on the three network factors with respect to the dependent variable.

First of all, we introduce the control variables (size, group, and age of the firm) in our base model. In Model 1, we establish the positive relationships of the independent variables with regard to eco-innovation. In Model 2, we add the squared variables to test whether this relationship is inverted U-shaped.

In the base and the following models, significant and positive values can be observed for the control variable of firm size with respect to environmental motivations, in line with the results obtained by Cuerva et al. (2014). It is the large firms that are most inclined to innovate in this regard (Pereira \& Vence, 2012). This is explained by a series of internal and external factors. Internally, as noted by Chen (2008), larger industrial firms incorporate "green management" into their organization and running, creating policies that favor the environment and investing in technology that increases the competitive advantages of the firm.

De Marchi (2012) notes that larger firm size is associated with the creation of internal education programs on environmental sustainability for employees, which makes ecoinnovation projects more successful. These two questions also affect external aspects, as noted by Cainelli et al. (2012), whereby large firms usually cooperate more frequently with "qualified" agents such as universities or suppliers with expertise in environmental matters. This opportunity is only exploited by large firms, and benefits the development of improved products which, along with the assimilation capacity enabled by employee training, enhance results. We present the numerical results in Table 5. 
Avellaneda-Rivera, L.M., González-Moreno, A. \& Sáez-Martínez, F.J. (2018). The Pursuit of External Knowledge in Eco-Innovation. Analysis of the Agri-Food Sector in Spain. Journal of Business, Universidad del Pacífico (Lima, Peru) Vol.10 (1): 70-92

Table 5. MCO regression analysis. Agri-food sector.

\begin{tabular}{|c|c|c|c|c|c|c|}
\hline & \multicolumn{2}{|c|}{ Base Model } & \multicolumn{2}{|c|}{$\begin{array}{l}\text { Model } 1 \\
\text { Hypotheses 1a, 2a } \\
\text { and 3a }\end{array}$} & \multicolumn{2}{|c|}{$\begin{array}{l}\text { Model } 2 \\
\text { Hypotheses 1b, 2b } \\
\text { and } 3 b\end{array}$} \\
\hline & $ß$ & $\begin{array}{l}\text { Error } \\
\text { Est }\end{array}$ & $ß$ & $\begin{array}{l}\text { Error } \\
\text { Est }\end{array}$ & $ß$ & $\begin{array}{l}\text { Error } \\
\text { Est }\end{array}$ \\
\hline Constant & -2.066 & 3.616 & -4.588 & 3.026 & -5.147 & 2.966 \\
\hline Size (Ln employees) & $0.160 * * *$ & .033 & $0.086 * * *$ & 0.028 & $0.077 * * *$ & 0.028 \\
\hline Group & -0.27 & 0.092 & -0.063 & 0.077 & -0.030 & 0.077 \\
\hline Year of creation & 0.001 & 0.002 & 0.001 & 0.002 & 0.001 & .001 \\
\hline Breadth of sources & & & 0.036 & 0.029 & 0.025 & 0.065 \\
\hline Depth of sources & & & $0.095 * * *$ & 0.007 & $0.273 * * *$ & 0.034 \\
\hline Geographical diversity & & & -0.022 & 0.054 & -0.032 & 0.129 \\
\hline Amplitud $^{2}$ & & & & & 0.008 & 0.012 \\
\hline Profundidad $^{2}$ & & & & & $-0.005 * * *$ & 0.001 \\
\hline Diversidad Geografica ${ }^{2}$ & & & & & 0.003 & 0.028 \\
\hline $\mathbf{R}^{2}$ ajustado & 0.043 & & 0.335 & & 0.362 & \\
\hline $\mathbf{F}$ & $9.954 * * *$ & & $50.541 * * *$ & & $38.222 * * *$ & \\
\hline
\end{tabular}

When it comes to relationship intensity (depth) in cooperation, our assertion regarding the relationship with eco-innovation is confirmed, with a positive and significant value obtained in models 1 and 2. Cognitive proximity favors learning through networks of cooperation, since it alters, shares, and exploits knowledge based on the needs of each firm (Spila et al., 2009). The speed with which this knowledge is assimilate will depend on the organizational structure. Agri-food firms face difficulties in finding suitable partners or agents, thus hampering openness to innovation on account of distrust (Rennings \& Rammer, 2009). However, if in this process they succeed in adapting their needs with a suitable source of information, they will end up forging stable links through an interactive process (Amara et al., 2008). In environmental terms, the creation of formal or informal links provides additional inputs for the learning process, thus creating new opportunities for access to information about markets, technologies, and research. The results coincide with the findings of Montresor et al. (2013) who state that a deep relationship with actors close to one's own environment will enhance the prospects of achieving ecoinnovating processes. Thus, Hypothesis $2 \mathrm{a}$, on the depth of external relationships in cooperation, holds true.

In models 1 and 2, we do not obtain significant values for the variable of breadth. The manufacturing industries tend to place greater importance on the concept of depth than that of breadth, as posited by Laursen \& Salter (2006). There is a need on the part of these manufacturing firms for intense cooperation with agents so as to solve and avoid possible problems with information processing (Simon, 1947), since the entrepreneurs' decision-making capacity is limited, and they prefer to do so with agents in their trust. A large number of ideas will impede the adequate selection and exploitation of processes (Koput, 1997). Thus, as regards environmental concerns, there is a need for the multitudinous interests of the various external agents to be filtered and reduced, prioritizing and selecting those most attuned to the firm's interests (Ketata et al., 2015); as such, Hypothesis 1a, on the breadth of cooperation networks, does not hold. 
In the results obtained through the regression in the sample of the agri-food sector, it can be seen that the variable of geographical diversity has a negative and non-significant value, without the conclusive results recorded by Horbach (2008), who observed positive effects on eco-innovation, or Barge-Gil (2010), who pointed to a positive effect, citing this as a possible solution for non-technology-intensive firms in the search for innovative solutions. This may be due to dispersion of the interests of the multiple actors, which can greatly increase the management of information processing demands; as a result, organization becomes more complex, making it difficult to achieve eco-innovation. Through the statistical results, we have noted the low frequency of firms in the search for international geographical channels, associated with higher costs and greater uncertainty due to absorption costs (Cohen \& Levinthal, 1990, Laursen \& Salter, 2006), and to the costs associated with opportunistic behavior (Faems et al., 2010) assumed by industrial firms, without knowing in advance what effect this behavior will have on results.

Moreover, if the geographical diversity is international, the cognitive distance will be greater, which increases spending on resources, and the time required for assimilation and usage, all the more. This sector exhibits a distrust with respect to the openness of innovation to various sources of knowledge, and looks instead to links close to its network and value chain such as customers (Herstatt \& Von Hippel, 1992; Boutellier et al., 2008, Hienerth, 2006) or suppliers (Bigliardi et al., 2010) as "trusted" sources for cooperation in terms of process, product, and environmental innovation. Thus, Hypothesis $3 a$, regarding the favorable effect of geographical source diversity on ecoinnovation, does not hold true.

In Model 2, we add the independent squared variables, where we prove that Hypothesis $2 a$ regarding depth is positive and significant $(0.273$ at $99 \%)$. As to the effect of the inverted $U$ on eco-innovation, the above table 5 shows the variable of depth ${ }^{2}$ to be negative and significant (-0.005 at 99\%), demonstrating that an excess thereof in the links established with sources of cooperation can have a negative effect on ecoinnovation. This is due, primarily, to excessive use of the same trusted sources, which fail to obtain technology that is appropriate (and that which they do obtain is obsolete) for addressing ecological problems; and second, because the increasing costs of obtaining this information are not offset by the results obtained. Ghisetti et al. (2013) suggest that a conflict exists between engagement in the intense pursuit of external knowledge and the capacity to implement environmental improvement measures.

In traditional or mature sectors removed from the new technologies, the greater complexity can have repercussions on the lack of knowledge, and, in turn, if the distance of the external knowledge is greater, there can be a loss of attention and assimilation on the part of the eco-innovator. The relative scarcity of specific green competencies can place greater pressure on the attention of the company's resources, thus decreasing its performance.

In general terms, we find that greater depth in the cooperation relationship has a positive bearing on eco-innovation development - although this relationship is inverted $U$ shaped, as shown in the graph 1. 


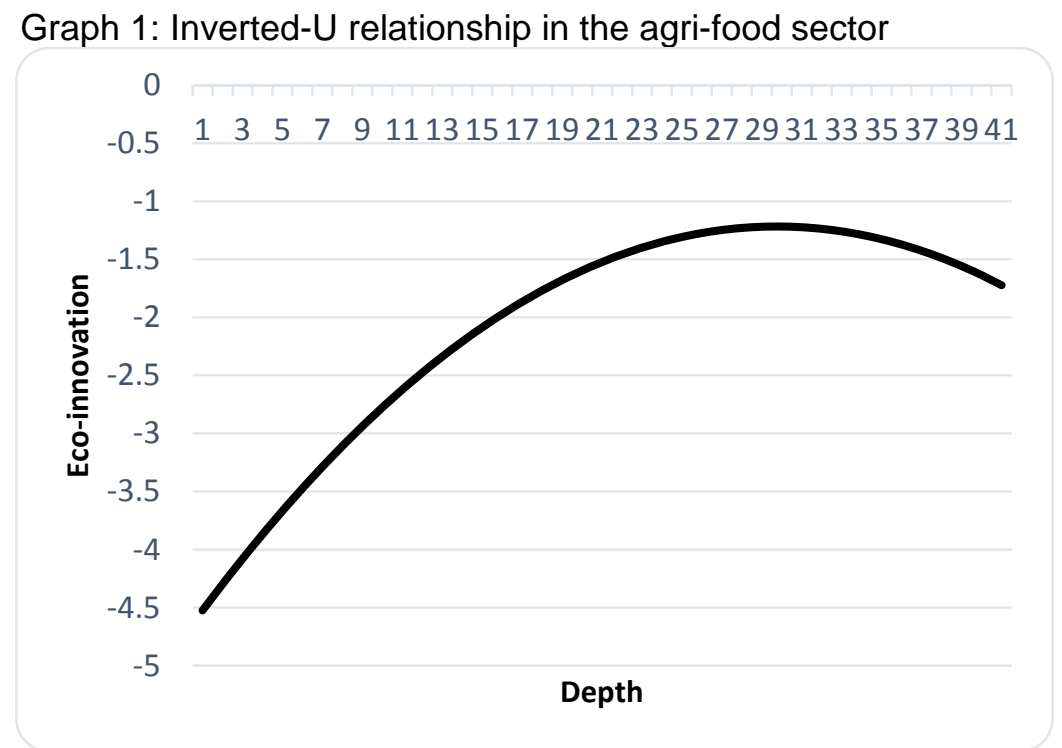

\section{Conclusions}

While the literature has focused on the consequences of environmental changes in large companies (Laperche \& Uzunidis, 2012), our research has advanced in the study of a sector chiefly composed of small firms in low-technology sectors. The sample we have analyzed pertains to the agri-food sector, characterized by a competitive environment in which firms innovate to gain competitive advantages (Costa \& Jongen, 2006), in a market where products are generally homogenous (Cuerva et al., 2014) and where the consumer plays an important role in the shift towards healthy eating (Sarkar \& Costa, 2008; Zhuan et al., 2016) and responsibility for waste management. It is vital that agrifood firms increase their competitiveness in order to continue facilitating and stimulating economic growth based on relevant business strategies aimed at improving competitiveness through innovation (Castillo-Valero \& García-Cortijo, 2017).

Our contribution confirms that the environmental innovations made by firms in the agrifood sector are influenced positively by interaction with external actors. Intense and sustained cooperation with a suitable partner (whether through formal or informal links) is decisive, and a crucial asset for acquiring, through interaction, the necessary learning to solve problems (Amara et al., 2008). Ongoing relationships with external sources facilitate learning and trust on the part of firms, as interactions always furnish the firms with more refined knowledge and increase the likelihood of introducing environmental improvements. However, our results show that an excess of trust in the links established with sources of cooperation can have negative effects on eco-innovation. This is due, primarily, to excessive use of the same sources of trust, which fail to obtain technology that is appropriate (and that which they do obtain is obsolete) for addressing environmental problems; and second, because the increasing costs of obtaining this information are not offset by the results obtained. The adoption of eco-innovative measures depends on the firm's perception of environmental matters (Del Rio, 2011), which are formalized as environmental strategies associated with the organization (Tsen et al., 2013; Cuerva et al., 2014).

As to limitations, our study analyzes a specific practice of open innovation: namely, cooperation agreements. Some mechanisms that are beyond the scope of this study, such as externalization and the purchase of licenses, could aid understanding of the 
differences between practices in the search for external sources. Moreover, it should be noted that this study takes a static, cross-sectional approach to analyzing certain variables that limit "causation." Thus, here we have sought to examine a key moment so as to understand a strategic behavior among firms, and in so doing we faced limitations arising from the use of a database that we did not design.

As noted by Chersbrough (2010), open innovation provides many opportunities for creating value through product differentiation and personalization. The studies that analyze the achievement of environmental improvements by mature external cooperation networks are scarce, given the heterogeneity of firm types; thus, a possible future line of research could analyze other sectors of industry with innovative behavioral patterns similar to the agri-food sector.

\section{References}

Ahuja, G. (2000). Collaboration networks, structural holes and innovation: A longitudinal study. Administrative Science Quarterly, 45(3), 425-455.

Ahuja, G. \& Katila, R. (2001). Technological acquisitions and the innovation performance of acquiring firms: A longitudinal study. Strategic Management Journal, 22(3), 197-220.

Amara, N., Landry, R., Becheikh, N. \& Ouimet, M. (2008). Learning and novelty of innovation in established manufacturing SMEs. Technovation, 28(7), 450-463.

Ángel, J., De la Fuente, B. \& Vila, A. (2011). Estadística. Barcelona. Publicaciones de la Universidad Oberta de Catalunya.

Arruda, C., Rossi, A., Mendes, G. \& Ferreira, P. (2013). The Influence of External Search Strategies on the Innovative Performance of Brazilian Firms. Journal on Innovation and Sustainability, 4(1), 2179-3565

Banerjee, S.B., Iyer, E.S. \& Kashyap, R.K. (2003). Corporate environmentalism: Antecedents and influence of industry type. Journal of Marketing, 67(2), 106-122.

Barge-Gil, A. (2010). Cooperation-based innovators and peripheral cooperators: An empirical analysis of their characteristics and behaviour. Technovation, 30(3), 195-206.

Bigliardi, B., Bottani, E. \& Galati, F. (2010). Open innovation and supply chain management in food machinery supply chain: A case study. International Journal of Engineering, Science and Technology, 2(6), 244-255.

Blasi, E., Monotti, C., Ruini, L., Landi, C., Avolio, G. \& Meriggi, P. (2015). Eco-innovation as a driver in the agri-food value chain: an empirical study on durum wheat in Italy. Journal on Chain and Network Science, 15(1), 1-15.

Bogers, M., Chesbrough, H. \& Moedas, C. (2018). Open Innovation: Research, Practices, and Policies. California Management Review, 60(2), 5-16.

Boland, M. (2008). Innovation in the food industry: Personalised nutrition and mass customisation. Innovation, 10(1), 53-60.

Bossle, M.B., De Barcellos, M.D., Vieira, L.M., \& Sauvée, L. (2016). The drivers for adoption of eco-innovation. Journal of Cleaner Production, 113, 861-872. 
Boutellier, R., Gassmann, O., \& Von Zedtwitz, M. (2008). Managing global innovation: uncovering the secrets of future competitiveness. Springer Science \& Business Media.

Brunnermeier, S. B., \& Cohen, M. A. (2003). Determinants of environmental innovation in US manufacturing industries. Journal of Environmental Economics and Management, 45(2), 278-293.

Brunswicker, S. \& Vanhaverbeke, W. (2011) Beyond open innovation in large enterprises: How do small and medium-sized enterprises (SMEs) open up to external innovation sources. Paperwork. 1-40, retrieved from https://papers.ssrn.com/sol3/papers.cfm?abstract_id=1925185

Bullinger, A.C., Neyer, A.K., Rass, M. \& Moeslein, K.M. (2010) Community-Based Innovation Contests: Where Competition Meets Cooperation. Creativity and Innovation Management, 19, 290-303.

Cainelli, G., De Marchi, V. \& Grandinetti, R. (2015). Does the development of environmental innovation require different resources? Evidence from Spanish manufacturing firms. Journal of Cleaner Production, 94, 211-220.

Cainelli, G., Mazzanti, M. \& Montresor, S. (2012). Environmental innovations, local networks and internationalization. Industry and Innovation, 19(8), 697-734.

Carrillo-Hermosilla, J., Del Río, P. \& Könnölä, T. (2010). Diversity of eco-innovations: Reflections from selected case studies. Journal of Cleaner Production, 18(10), 10731083.

Carrillo-Hermosilla, J., Del Río, P \& Könnölä, T. (2011) Eco-Innovación. Claves para la competitividad sostenible y la sostenibilidad competitiva. Editorial Netbiblo. Editoras Lorena Bello y Maria Martínez. Coord. Juan Vicente García Manjon y Marín de la Iglesia. Spain.

Castillo-Valero, J.S. \& García-Cortijo, M.C. (2013). Estrategias de las cooperativas agroalimentarias de la UE frente a la globalización: el caso de las cooperativas de vino. Cooperativismo y desarrollo, 1(1), 67-87.

Chen, Y.S. (2008). The driver of green innovation and green image-green core competence. Journal of Business Ethics, 81(3), 531-543.

Chen, J., Chen, Y. \& Vanhaverbeke, W. (2011). The influence of scope, depth, and orientation of external technology sources on the innovative performance of Chinese firms. Technovation, 31(8), 362-373.

Chesbrough, H.W. (2003) The era of open innovation. Mlt Sloan Management review. $44335-41$

Chesbrough, H. \& M. Bogers (2014). Explicating open in novation: clarifying an emerging paradigm for understanding innovation. In: Chesbrough, H. Vanhaver beke, W., \& J. West (Eds.) New Frontiers in Open Innovation , Oxford: Oxford University Press, 3-28.

Chesbrough, H. (2010). Business model innovation: opportunities and barriers. Long range planning, 43(2), 354-363.

Chesbrough, H., Vanhaverbeke, W. \& West, J. (Editores) (2014). New frontiers in open innovation. Published by OUP Oxford. 
Avellaneda-Rivera, L.M., González-Moreno, A. \& Sáez-Martínez, F.J. (2018). The Pursuit of External Knowledge in Eco-Innovation. Analysis of the Agri-Food Sector in Spain. Journal of Business, Universidad del Pacífico (Lima, Peru) Vol.10 (1): 70-92

Cohen, W.M. \& Levinthal, D.A. (1990). Absorptive capacity: A new perspective on learning and innovation. Administrative Science Quarterly, 128-152.

Costa, A.I. \& Jongen, W.M.F. (2006). New insights into consumer-led food product development. Trends in Food Science \& Technology, 17(8), 457-465.

Cuerva, M.C., Triguero-Cano, Á. \& Córcoles, D. (2014). Drivers of green and non-green innovation: empirical evidence in Low-Tech SMEs. Journal of Cleaner Production, 68, 104-113.

Dahlander, L. \& Gann, D.M. (2010). How open is innovation? Research Policy, 39(6), 699-709.

De Marchi, V. (2012). Environmental innovation and R\&D cooperation: Empirical evidence from Spanish manufacturing firms. Research Policy, 41(3), 614-623.

De Marchi, V. \& Grandinetti, R. (2012). Who are the green innovators? An empirical analysis of firm's level factors driving environmental innovation adoption. In Druid Conference ,19-21.

Del Río, P., Carrillo-Hermosilla, J., Könnölä, T. \& Bleda, M. (2016). Resources, capabilities and competences for eco-innovation. Technological and Economic Development of Economy, 22(2), 274-292.

Del Río, P., Peñasco, C. \& Romero-Jordán, D. (2016). What drives eco-innovators? A critical review of the empirical literature based on econometric methods. Journal of Cleaner Production, 112, 2158-2170.

Faems, D., De Visser, M., Andries, P. \& Van Looy, B. (2010). Technology Alliance Portfolios and Financial Performance: Value-Enhancing and Cost-Increasing Effects of Open Innovation. Journal of Product Innovation Management, 27(6), 785-796.

Fussler, C. \& James, P. (1996). A breakthrough discipline for innovation and sustainability. Pitman Publishing: London, UK.

Galang, RM.N. (2014). Divergent diffusion: Understanding the interaction between institutions, firms, networks and knowledge in the international adoption of technology. Journal of World Business, 49(4), 512-521.

Gandoy-Juste. R, \& González Díaz, B. (2004). El comportamiento de la industria tradicional: crecimiento y competitividad. Economía Industrial, 335, 336-350..

Garriga, H., Von Krogh, G. \& Spaeth, S. (2013). How constraints and knowledge impact open innovation. Strategic Management Journal, 34(9), 1134-1144.

Ghisetti, C., Marzucchi, A. \& Montresor, S. (2015). The open eco-innovation mode. An empirical investigation of eleven European countries. Research Policy, 44(5), 10801093.

Goerzen, A. \& Beamish, P.W. (2005). The effect of alliance network diversity on multinational enterprise performance. Strategic Management Journal, 26(4), 333-354. 
González-Moreno, Á., Sáez-Martínez, F. J. \& Díaz-García, C. (2013). Drivers of EcoInnovation in Chemical Industry. Environmental Engineering \& Management Journal (EEMJ), 12(10).

Grunert, K.G. (2005). Food quality and safety: consumer perception and demand. European Review of Agricultural Economics, 32(3), 369-391.

Gulati, R, Zaheer, A. \& Nohria, N. (2000). Strategic networks. Strategic Management Journal, 21(3), 203.

Hemmelskamp, J. (1999). The influence of environmental policy on innovative behaviour: an econometric study. Fondazione Eni Enrico Mattei. Working Paper, (18.99).

Herstatt, C. \& Von Hippel, E. (1992). From experience: Developing new product concepts via the lead user method: A case study in a "low-tech" field. Journal of product innovation management, 9(3), 213-221.

Hewitt-Dundas, N. \& Roper, S. (2017). Exploring market failures in open innovation. International Small Business Journal, 08.02.2017.

Hienerth, C. (2006). The commercialization of user innovations: the development of the rodeo kayak industry. R\&d Management, 36(3), 273-294.

Hölzl, W. (2009). Is the R\&D behaviour of fast-growing SMEs different? Evidence from CIS III data for 16 countries. Small Business Economics, 33(1), 59-75.

Horbach, J. (2008). Determinants of environmental innovation-new evidence from German panel data sources. Research Policy, 37(1), 163-173.

Horbach, J., Rammer, C. \& Rennings, K. (2012). Determinants of eco-innovations by type of environmental impact-The role of regulatory push/pull, technology push and market pull. Ecological Economics, 78, 112-122.

Horbach, J., Oltra, V. \& Belin, J. (2013). Determinants and specificities of ecoinnovations compared to other innovations-an econometric analysis for the French and German industry based on the community innovation survey. Industry and Innovation, 20(6), 523-543.

Horbach, J. (2014). Do eco-innovations need specific regional characteristics? An econometric analysis for Germany. Review of Regional Research, 34(1), 23-38.

Instituto Nacional de Estadística. Accessed in June 2017. Retrieved from: http://www.ine.es

Katila, R. \& Ahuja, G. (2002). Something old, something new: A longitudinal study of search Behavior and new product introduction. Academy of Management Journal, 45(6), 1183-1194.

Kesidou, E. \& Demirel, P. (2012). On the drivers of eco-innovations: Empirical evidence from the UK. Research Policy, 41(5), 862-870.

Ketata, I., Sofka, W. \& Grimpe, C. (2015). The role of internal capabilities and firms' environment for sustainable innovation: evidence for Germany. R\&d Management, 45(1), 60-75. 
Avellaneda-Rivera, L.M., González-Moreno, A. \& Sáez-Martínez, F.J. (2018). The Pursuit of External Knowledge in Eco-Innovation. Analysis of the Agri-Food Sector in Spain. Journal of Business, Universidad del Pacífico (Lima, Peru) Vol.10 (1): 70-92

Knudsen, M.P. (2007). relative importance of interfirm relationships and knowledge transfer for new product development success. Journal of Product Innovation Management, 24(2), 117-138.

Koput, K.W., (1997) A chaotic model of innovative search: some answers, many questions. Organization Science, 8 (5), 528-542.

Kostopoulos, K.C., Brachos, D.A., Philippidou, S.S. \& Katsikis, I.N. (2010). Knowledgebased approaches in strategic management: a review of the literature. International Journal of Applied Systemic Studies, 3(4), 389-403.

Laperche, B. \& Uzunidis, D. (2012). Eco-innovation, knowledge capital and the evolution of the firm. IUP Journal of Knowledge Management, 10(3), 14-34.

Laursen, K. \& Salter, A. (2006). Open for innovation: the role of openness in explaining innovation performance among UK manufacturing firms. Strategic Management Journal, 27(2), 131-150.

Lee, S., Park, G., Yoon, B. \& Park, J. (2010). Open innovation in SMEs. An intermediated network model. Research Policy, 39(2), 290-300.

Leiponen, A. \& Helfat, C.E. (2005). Innovation objectives, knowledge sources and the benefits of breadth. Unpublished manuscript from Cornell University. Ithaca, New York.

Levinthal, D.A. \& March, J.G. (1993). The myopia of learning. Strategic Management Journal, 14(S2), 95-112.

Lichtenthaler, U. (2009). Absorptive capacity, environmental turbulence, and the complementarity of organizational learning processes. Academy of Management Journal. 52(4), 822-846.

March, J.G. (1991). Exploration and exploitation in organizational learning. Organization Science, 2(1), 71-87.

Maula, M., Keil, T. \& Salmenkaita, J. P. (2006). Open innovation in systemic innovation contexts. Open innovation: researching a new paradigm, Oxford University Press. (12) 241-257.

Mogensen, A., Poensgen, A., Figge, C. \& Campanella, V. (2012) Green crowdsourcing: The role of social media for growing eco-product demand and eco-innovation. Electronics Goes Green (1-6). September 2012. IEEE..

Montresor, S., Ghisetti, C. \& Marzucchi, A. (2013). The "green-impact" of the open innovation mode. Policy Brief, European Commision. Joint Research Centre.1-13.

Mowery, D (1992) The U.S. national innovation system: origins and prospects for change. Elsevier Science Publishers B.V, 21, 125-144.

Nieto, M.J. \& Santamaría, L. (2007). The importance of diverse collaborative networks for the novelty of product innovation. Technovation, 27(6), 367-377.

Ocasio, W. (1997). Towards an attention-based view of the firm. Strategic Management Journal, 187-206. 
Avellaneda-Rivera, L.M., González-Moreno, A. \& Sáez-Martínez, F.J. (2018). The Pursuit of External Knowledge in Eco-Innovation. Analysis of the Agri-Food Sector in Spain. Journal of Business, Universidad del Pacífico (Lima, Peru) Vol.10 (1): 70-92

OECD (2010). Eco-innovation in Industry: Enabling Green Growth. Organisation for Economic Cooperation and Development, Paris. France.

Arza, V. (2008). Environmental innovation and industrial dynamics: the contributions of evolutionary economics. Cahiers du Gretha. 28, 27.

Peñasco, C., Del Río, P. \& Romero-Jordán, D. (2014, January). Analysing the role of international drivers for eco-innovators. In ISPIM Conference Proceedings (p. 1). The International Society for Professional Innovation Management (ISPIM).

Pereira, Á. \& Vence, X. (2012). Key business factors for eco-innovation: an overview of recent firm-level empirical studies. Cuadernos de Gestión 12, 73-103.

Powell, W.W., Koput, K.W. \& Smith-Doerr, L. (1996). Interorganizational collaboration and the locus of innovation: Networks of learning in biotechnology. Administrative Science Quarterly, 116-145.

Presutti, M., Boari, C., Majocchi, A., \& Molina-Morales, X. (2017). Distance to Customers, Absorptive Capacity, and Innovation in High-Tech Firms: The Dark Face of Geographical Proximity. Journal of Small Business Management.

Rennings, K. (2000). Redefining innovation-eco-innovation research and the contribution from ecological economics. Ecological Economics, 32(2), 319-332.

Rennings, K. \& Rammer, C. (2009). Increasing energy and resource efficiency through innovation-an explorative analysis using innovation survey data. ZEW-Centre for European Economic Research Discussion, (09-056).

Reyes Santiago, M.R \& Sánchez-Medina P. S. (2016) Eco-Innovación en Empresas Hoteleras de Oaxaca, Salud y Administración. 3(8), 27-37.

Roth, K. (1992). International configuration and coordination archetypes for mediumsized firms in global industries. Journal of International Business Studies, 23(3), 533549.

Sáez-Martínez, F.J., Avellaneda-Rivera, L. \& González-Moreno, Á. (2016). Open and Green Innovation in the Hospitality Industry. Environmental Engineering \& Management Journal (EEMJ), 15(7), 1481-1487.

Santamaría, LI., Rodríguez, A. \& Nieto, M.J. (2016). The dark and bright sides of collaboration: the effects of geographic proximity and the international diversity of partners on innovation success and failure. Workpaper of the XXVI Congreso Nacional de ACEDE. June 2016. Vigo.

Sarkar, S. \& Costa, A.I. (2008). Dynamics of open innovation in the food industry. Trends in Food Science \& Technology, 19(11), 574-580.

Segarra-Oña, M.V., Peiró-Signes, A., Albors-Garrigós, J. \& Miret-Pastor, P. (2011). Impact of innovative practices in environmentally focused firms: moderating factors. International Journal of Environmental Research, 5(2), 425-434.

Simon H.A. (1947) Administrative Behavior: A Study of Decision-Making Processes in Administrative Organizations. New York: Free Press. 
Spila, J.C., Rocca, L. \& Ibarra, A. (2009). Capacidad de absorción y formas de aprendizaje para la innovación: un modelo conceptual. Projectics/ Proyéctica/ Projectique, (1), 63-76.

Srholec, M. (2015). Understanding the diversity of cooperation on innovation across countries: Multilevel evidence from Europe. Economics of Innovation and New Technology, 24(1-2), 159-182.

Steen, M. \& Vanhaverbeke, W. (2016). Successful Open Innovation Involving SMEs: Network Structure and Network Coordination. in ISPIM Innovation Symposium (June 2016).

Teece, D.J., Pisano, G. \& Shuen, A. (1997). Dynamic capabilities and strategic management. Strategic Management Journal, 509-533.

Terjesen, S., \& Patel, P. C. (2017). In search of process innovations: The role of search depth, search breadth, and the industry environment. Journal of Management, 43(5), 1421-1446.

Tseng, M.L., Tan, R.R., \& Siriban-Manalang, A.B. (2013). Sustainable consumption and production for Asia: sustainability through green design and practice. Journal of Cleaner Production, 40, 1-5.

Triguero, A., Moreno-Mondéjar, L., \& Davia, M. A. (2013). Drivers of different types of eco-innovation in European SMEs. Ecological Economics, 92, 25-33.

Van De Vrande, V., De Jong, J.P., Vanhaverbeke, W., \& De Rochemont, M. (2009). Open innovation in SMEs: Trends, motives and management challenges. Technovation, 29(6), 423-437.

Vanhaverbeke, W. \& Cloodt, M. (2006). Open innovation in value networks. Open innovation: Researching a new paradigm, 258-281.

Weng, H.H.R., Chen, J.S. \& Chen, P. C. (2015). Effects of green innovation on environmental and corporate performance: A stakeholder perspective. Sustainability, 7(5), 4997-5026.

West. J \& Bogers, M (2017) Open innovation: current status and research opportunities. Innovation: Organization \& Management, 19(1), 43-50.

Wu, J. \& Wu, Z. (2014). Local and international knowledge search and product innovation: The moderating role of technology boundary spanning. International Business Review, 23(3), 542-551.

Yu, GJ. \& Rhee, SY. (2015). Effect of R\&D Collaboration with Research Organizations on Innovation: The Mediation Effect of Environmental Performance. Sustainability, 7(9), 11998-12016.

Zhuang, K. \& Jiang, Y. (2016). An analysis of the Development of the Chinese Fast Food Industry. Journal of Asian Business Strategy, 6(5), 85-100. 